\title{
Development potential of Beef Cattle under the Coconut Trees in east Bolangitang district Regency of North Bolaang Mongondow
}

\author{
Artise H.S. Salendu, Meiske L. Rundengan, Femi H. Elly, Tilly F.D. Lumy
}

Faculty of Animal Husbandry University of Sam Ratulangi Manado, North Sulawesi, Indonesia

\begin{abstract}
Farmers in East Bolangitang District, Indonesia were trying to increase beef cattle population as a source of their income, but the problem was the lack of feed caused by cattle being cultivated on agricultural land. The purpose of this study was to determine the potential for land development under coconut trees for forage. The research method used was a survey method, with the determination of the location was by purposive sampling, namely three villages that have the largest cattle population. The data collected was primary and secondary data with the type of data was cross section and time series. Respondents were determined by purposive sampling, namely 40 farmers who use land under coconut. Analysis of the data used descriptive analysis. Coconut area was 0.2-2 Ha or the average was 0.94 Ha. 35 percent ownership status by farmers and 65 percent farmers as tenants. Beef cattle ownership was 148 or 2-6 cattle per farmer. Feed consumption per head per day consisted of $6.21 \mathrm{~kg}$ of grass, $10.40 \mathrm{~kg}$ of corn waste and $6.26 \mathrm{~kg}$ of rice waste. Forage production for $0.94 \mathrm{Ha}$ can be utilized by $8.83 \mathrm{ST}$. In conclusion, coconut land in the study area has the potential to be used as a forage development. Need for socialization for farmers to introduce quality forage.
\end{abstract}

Keywords-beef cattle, land, coconut, potential.

\section{INTRODUCTION}

The phenomenon of achieving self-sufficiency in beef, which is difficult to achieve, was influenced by various factors, including the insufficient population of beef cattle. The production of beef in the regions, maintained traditionally, is expected to sustain national demand for meat. This includes local cattle raised by small farmers in rural areas (Rusdiana, 2019).

However, the required beef production is closely related to the availability of feed both in quantity and quality. The availability of forage for both quantity and quality depends on the land potential of each area.In addition, quantity and quality of forage in the tropics, fluctuatesespecially during the dry season resulting in a decrease in the level of productivity of beef cattle (Osak, et al, 2020).

Several studies conducted indicate that beef cattle farmers face various constrains related to feed. Their land use cause less land to be used for the development of feed. Transfer of land functions was a problem faced by various areas of beef cattle development (Mulyani et al, 2016; Elly

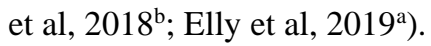

Cattle farmers and the government were trying to solve the forage problem in the development of beef cattle. Beef cattle must be encouraged considering the need for beef every year has increased. Beef cattle as ruminants have the largest contribution as a meat producer. This contribution really supports the fulfillment of food needs, especially animal protein. In addition, beef cattle has a role in income distribution and has a significant market potential (Rusdiana and Talib, 2019).

Beef cattle farmers in East Bolangitang District were trying to increase the beef cattle population as their source of income. Increasing the productivity of beef cattle farming as an effort to increase economic growth in rural areas is aimed at increasing the added value and income of farmers (Romjali, 2018).On the other hand, the development of beef cattle is regionally intended to supply the shortage of beef availability. This means that beef cattle in the regions have the opportunity to support beef demand, where the demand continues to increase from year to year. 
The need for national beef consumption has not been fulfilled, even beef tends to be in deficit until 2018 (Sodiq et al, 2018). Beef cattle farming is developed so that the population achieved is balanced with the need for food consumption from animal origin (Rusdiana and Praharani, 2018).In an effort to develop beef cattle in a region, it is necessary to analyze the potential of the area and density of beef cattle for the development of livestock farming in a development areaincluding in the coconut land area (Osak et al, 2019).

The problem was that the productivity of beef cattle in this area was low due to many constrains. Lack of feed because cattle were grazed on agricultural land was one of constrainsfaced by farmers. Whereas in this area the land under thecoconut trees has not been optimally utilized.Other farmers grow food crops under coconut trees and the waste was used as feed. However, the quality of food crop waste was considered low, especially dry waste. The problem was the extent to which the land under coconut trees can be used for forage development. Based on the background and thinking above, a study has been carried out related to the use of land under coconut trees. The purpose of this study was to determine the potential for land development under coconut trees through the introduction of forage.

\section{RESEARCH METHODS}

The research method used was a survey method of farmers through interviews using a questionnaire. The research location was determined by purposive sampling, namely three villages (Bohabak, Binjeta and Nunukan). The sample villages were determined based on the consideration that they had the largest cattle population. The data collected are primary and secondary data with the type of data is cross section and time series data. Respondents were determined by purposive sampling, namely 40 farmers who use the land under coconut trees. Data analysis using descriptive analysis.

\section{RESULTS AND DISCUSSION}

Farmers develop beef cattle as a side business. This condition was supported by various studies related to rural beef cattle farming. The main occupation of the respondents was as a farmer (100 percent). This condition was supported by the potential of research areas in agricultural development, such as the availability of dry land and rice fields. Potential areas that were managed optimally will support the successful development of the livestock subsector (Yulia et al, 2015).
Most of the farmers in the research locations developed food crop farming, both in open land and under coconut trees. The area of coconut land used by farmers was 0.2-2 $\mathrm{Ha}$ or an average of $0.94 \mathrm{Ha}$. The results showed that the status of coconut land, 35 percent belonged to farmers and 65 percent of farmers were cultivators. The land under coconut trees was used for grazing cattle. The number of cattle ownership was 148 head or 2-6 head per farmer. Various attempts were made to increase the scale of the business, including the government in this case facilitating the increase in business scale ([Kementerian Pertanian, 2017). Cattle in the research area were grazed during the day and transferred from one coconut field to another.

Farmers have not built stables so cattle were left on the farm. The respondent's cattle consume grass that grows wild under coconut trees. Corn and rice waste was also used as cattle feed in the research area. The consumption of cattle feed at the research location can be seen in Table 1 .

Table 1. Consumption of Feed by Beef Cattlein Research Location

\begin{tabular}{llcc}
\hline No. & \multicolumn{1}{c}{$\begin{array}{c}\text { Feed } \\
\text { Consumption }\end{array}$} & $\begin{array}{c}\text { Total } \\
(\mathrm{Kg} / \text { Cattle/Day })\end{array}$ & $\%$ \\
\hline 1. & Grass & 6,21 & 27,16 \\
2. & Corn Waste & 10,40 & 45,47 \\
3. & Rice Waste & 6,26 & 27,37 \\
\hline & T o t a l & 22,87 & 100,00 \\
\hline
\end{tabular}

Data Table 1 shows that the amount of corn waste was the largest consumption of beef cattle (45.47 percent). Then followed by the amount of rice waste by 27.37 percent and grass 27.16 percent. Agricultural waste of food crops in the area can be relied on as cattle feed. Beef cattle farming was generally integrated with food crops (Susanti et al, 2014). A waste management strategy was needed to support the development of beef cattle.

The problem was that the quality of dry food crop waste is low. The indication is the need for the introduction of technology to improve the quality of the food crop waste. This is because the feed given to cattles must contain good nutritional value (Saputra et al, 2016). The land under coconut trees and other idle land can be used for forage development. This condition shows that the land for forage development in the research area is not an obstacle. However, the importance of land cannot be ignored even though its role is small (Nur et al, 2018). The grass that was developed by some farmers in North Bolaang Mongondow Regency was dwarft grass. The 
results showed that forage production for $0.94 \mathrm{Ha}$ could be utilized by $8.83 \mathrm{AU}$. $1 \mathrm{Ha}$ of coconut land, if the contents were calculated to be $0.8 \mathrm{Ha}$, it requires 16,000 cuttings of dwarft grass. The grass was planted with $1 \mathrm{~m} \mathrm{X} 0.5 \mathrm{~m}$, and the grass production obtained was $4 \mathrm{~kg}$ per $\mathrm{m} 2$. The grass under the coconut tree can be cut 9 times per year, which means that it produces 288 tons per year per Ha. The amount produced was 288 tons equivalent to 22.5 Animal Units / year (Salendu and Elly, 2012). Types of dwarft grass that can be developed in the study area can be seen in Figure 1.

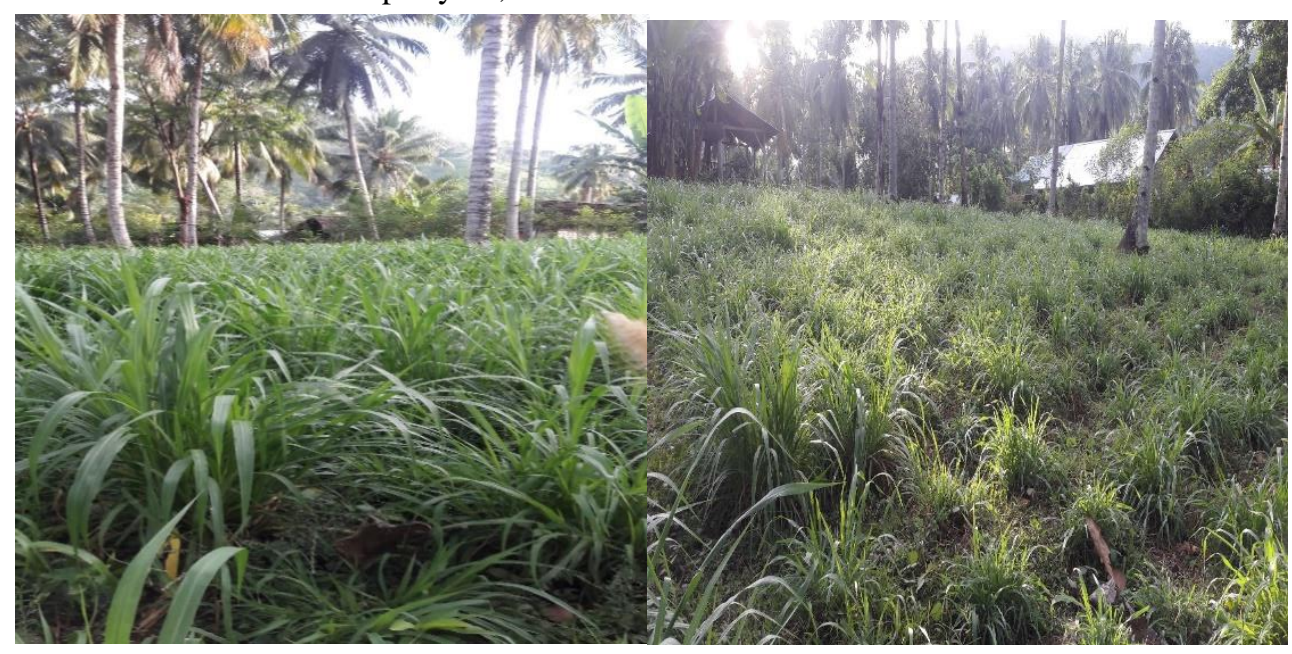

Fig.1: Dwarft grass developed under coconut trees

Figure 1 shows that the land under the coconut can be used by farmers to support feed needs in the study area. The introduction of this grass was carried out in other areas and responded well by the farming community. The grass has been given to cattle developed with cage systems (Elly et al, 2018 a andElly et al, 2019 b).

\section{CONCLUSIONS}

Basedonthe research results, coconut land in the study area has the potential to be used as a forage development. Need for socialization for farmers to introduce quality forage.

\section{ACKNOWLEDGMENTS}

Thanks to the Rector, the Chairman and the Secretary LPPM, and Dean of the Faculty of Animal Husbandry Sam Ratulangi University, which has provided an opportunity for the autor to conduct research with PNBP funds for Skim RTUU.

\section{REFERENCES}

[1] Elly, F.H., A.H.S. Salendu, Ch. L. Kaunang, Indriana, R. Pomolango, and Syarifuddin. 2018 (b). Forage Introduction to Support Development of Cattle in Sangkub District. International Journal of Environment, Agriculture and Biotechnology3(5):1718-1720.
[2] Elly, F.H., A. Lomboan, C. L. Kaunang and R. Pomolango. 2019 (a). Benefits of Integrated Farming System for Cattle Crops in North BolaangMongondow Regency North Sulawesi Province, Indonesia. International Journal of Agriculture, Environment and Bioresearch 4(4):1-5.

[3] Elly, F.H., A.H. Salendu., Ch. L. Kaunang., Indriana., Syarifuddin and R. Pomolango. 2018 ${ }^{(a)}$. Empowerment of Farmers in Efforts to Develop Sustainable Cattle Farming in Sangkub District Regency of North BolaangMongondow, North Sulawesi Province, Indonesia. Proceeding The Fourth International Seminar on Animal Industry. IPB International Convention Centre,Bogor Indonesia, August, 28-30 2018.

[4] Elly, F.H., A. Lomboan., Ch. L. Kaunang., M. Rundengan and Syarifuddin. 2019 (b). Development Potential of Integrated Farming System (Local Cattle-Food Crops). J. Animal Production. 21(3):143-147.

[5] Ministry of Agriculture. 2017. Government Policy in Developing Beef Cattle Farms in Indonesia. Directorate General of Animal Husbandry and Animal Health, Ministry of Agriculture, Jakarta.

[6] Mulyani, A., D. Kuncoro, D. Nursyamsi, and F. Agus. 2016. Paddy Field Conversion Analysis: Use of HighResolution Spatial Data Shows Alarming Conversion Rates. Journal of Soil and Climate 40(2):121-133.

[7] Nur, T.M., C. Fadli, and H. Satriawan. 2018. Analysis of Potential Integration of Cattle Oil Palm in Bireuen Regency, Aceh Province. Journal of Agribusiness and Rural Develpoment Research. 4(2):69-80.

[8] Osak,R.E.M.F., Anis, S.D. and Rumambi, A., 2020. Replacement of Napier grass with legume tree foliage in the coconut-beef cattle integrated farming system (Coco-Beef 
IFS). Livestock Research for Rural Development 32(1)Retrieved September 30, 2020, from http://www.lrrd.org/lrrd32/ 1/richa32014.html

[9] Osak, R.E.M.F., Lumy, T. D. F., andOroh, F. N., 2019.Cattle Density Analysis for Development of Cattle Farming in Coconut Land Area in South Minahasa Regency, Indonesia. International Journal of Environment, Agriculture and Biotechnology 4(2):370-373.

[10] Romjali, E. 2018.Beef Cattle Innovation Development through Field Laboratory Approach.Journal of WARTAZOA 28(2):69-80.

[11] Rusdiana, S. 2019. The phenomenon of the need for food sourced from meat can be fulfilled by increasing beef cattle business in farmers. SOCA Journal 13(1): 61-83.

[12] Rusdiana, S and C. Talib. 2019. Government Policy Supports Increasing Beef Cattle Farmers' Business. SOCA: Journal of Agricultural Socio-Economics13(3):380-395.

[13] Rusdiana, S and L. Praharani, 2018. Beef Cattle Development: Beef Self-Sufficiency Policy and Livestock Business Feasibility. Journal of AgroEconomic Research Forum 36(2):97-116.

[14] Salendu, A.H.S.and F.H. Elly. 2012. Utilization of Land Under Coconut Trees for Cattle Feed in North Sulawesi. Pastura Journal 2(1):21-25.

[15] Saputra, J.I., Limanand Y. Wid. 2016. Analysis of Potential Development of Beef Cattle Farms in PesawaranRegency. Integrated Animal Husbandry Scientific Journal 4(2):115123.

[16] Sodiq, A., P. Yuwono, Y. N. Wakhidati, A. H. Sidhi, M. Rayhanand A. Maulianto. 2018. Beef Cattle Development through Cluster Programs: Program and Activity Description. Journal of Agripet 18(2):103-109.

[17] Susanti, Y., D. S. Priyarsonoand S. Mulatsih. 2014. Beef Cattle Farm Development for Economic Improvement of Central Java Province: A Regional Planning Approach. Journal of Indonesian Agribusiness 2(2):177-190.

[18] Yulia, L.M., Bagaand N. Tinaprilla. 2015. The Role and Development Strategy of the Animal Husbandry Subsector in the Development of Agam Regency, West Sumatra. Journal of Indonesian Agribusiness 3(2):159-176. 